\title{
Analyses of seismic activities and hazards in Laos: A seismicity approach
}

\author{
Santi Pailoplee* and Punya Charusiri \\ Morphology of Earth Surface and Advanced Geohazards in Southeast Asia Research Unit (MESA RU), Department of Geology, \\ Faculty of Science, Chulalongkorn University, Bangkok, Thailand
}

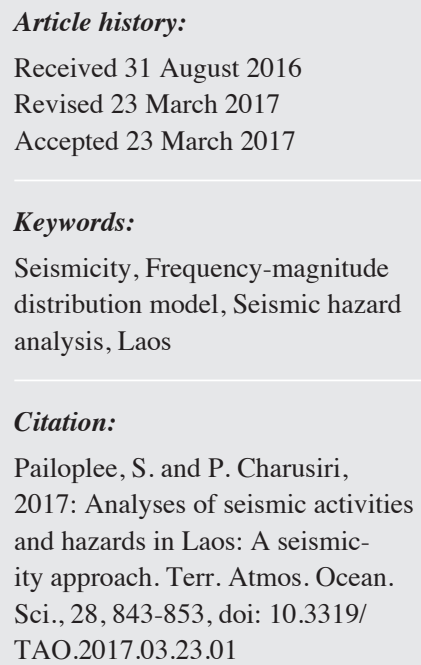

Citation:

Pailoplee, S. and P. Charusiri, 2017: Analyses of seismic activities and hazards in Laos: A seismicity approach. Terr. Atmos. Ocean. Sci., 28, 843-853, doi: 10.3319/ TAO.2017.03.23.01

\begin{abstract}
The seismic activities and hazards in People's Democratic Republic Laos were analyzed using the most up-to-date seismicity data. Both the a- and b-values of the frequency-magnitude distribution model, including the return period of earthquake magnitude in the range of $5.0-6.0 \mathrm{M}_{\mathrm{w}}$, were evaluated spatially in a region that extends $300 \mathrm{~km}$ from Laos. Six seismic source zones with different seismic activities were found. Based on these seismic source zones and a suitable attenuation model, seismic hazards were then analyzed in both deterministic and probabilistic scenarios. The deterministic map showed a possible maximum ground shaking up to $0.4 \mathrm{~g}$ in Northern Laos, whereas the ground shaking calculated from the probabilistic approach was $<0.32 \mathrm{~g}$ for $2 \%$ probability of exceedance in the next $50 \mathrm{yr}$. The probability of exceedance of an earthquake with a Modified Mercalli intensity scale of level IV - V, VI and VII in Laos in the next 50 yr was > 90, $70-90$, and $20-40 \%$, respectively, and was higher in the northern part. From these seismic activities and hazard analyses, Laos can be clearly separated into the three hazard zones of northwestern, northeastern and southern Laos with a high, medium and low earthquake hazard, respectively. Therefore, effective mitigation plans to reduce the impact of seismic hazards should be formulated and in particular for a number of major provinces located in the northern part of Laos.
\end{abstract}

\section{INTRODUCTION}

Although People's Democratic Republic Laos (hereafter called Laos) is far away from the major tectonic plate boundary (the Sumatra-Andaman Subduction Zone), the tectonic stress caused by the present-day Indian-Eurasian plate collision influences areas within the plate (Vergnolle et al. 2007). As a result, Laos and the adjacent areas are dominated by some inland seismogenic fault zones, such as the Dien Bien Phu (Zuchiewicz et al. 2004), Mae Ing (Fenton et al. 2003), Nam Ma (Morley et al. 2007), and the Red River (Duong and Feigl 1999) fault zones. Based mainly on instrumental earthquake records, a number of shallow crustal earthquakes have been recorded in the vicinity of Laos, and in particular in the northern part, during the last three decades of 1980 - 2015 (Fig. 1). Among these earthquake records, at least 17 large earthquakes with a $\mathrm{M}_{\mathrm{w}} \geq 6.0$, plus the three major earthquakes of the $\mathrm{M}_{\mathrm{w}}-7.0$ and $\mathrm{M}_{\mathrm{w}}-7.7$ in 1988 and the latest $\mathbf{M}_{\mathrm{w}}-7.1$ earthquake posed in 2011, have

\footnotetext{
* Corresponding author

E-mail:Pailoplee.S@gmail.com
}

been reported. Accordingly, Laos has experienced recent hazardous earthquake ground shaking.

Up to the present, the only seismic hazard map of Laos was a preliminary one developed by the United Nations Office for Coordination of Humanitarian Affairs (OCHA; http://ochaonline.un.org). This map, however, depicts the severity of earthquakes in terms of the Modified Mercalli Intensity (MMI) scale for a 250-yr return period. In order to serve the infrastructure and utility advancements in Laos according to the upcoming ASEAN Economics Community (AEC), seismic hazard maps showing the ground shaking distribution should be proposed, and so this was the main aim of this study.

\section{SEISMICITY DATA AND COMPLETENESS}

Within seismic hazard analysis (SHA), seismogenic faults are recognized as the major sources of earthquakes and local paleoseismological evidence is required for the determination of earthquake activities and in particular for 


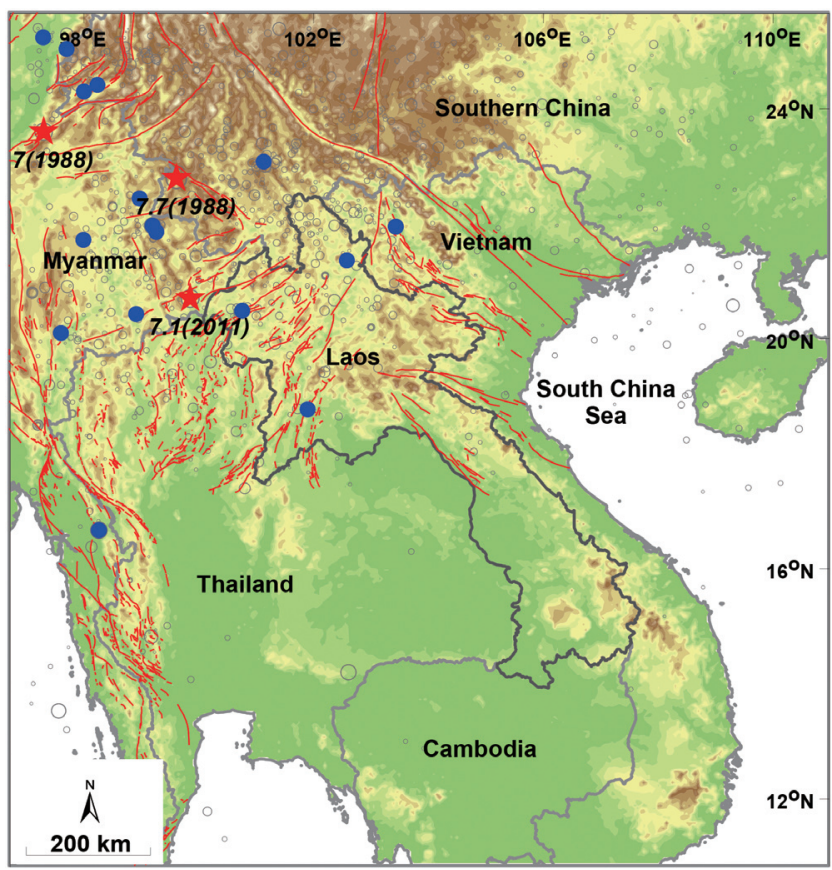

Fig. 1. Map of mainland Southeast Asia showing the epicentral distributions of the completeness earthquake data (grey circles). Earthquakes with a $\mathrm{M}_{\mathrm{w}} \geq 6.0$ and $\geq 7.0$ are illustrated as blue circles and red stars, respectively. The red lines delineated in the maps are the seismogenic faults previously proposed by Pailoplee et al. (2009). (1) Red River, (2) Nam Ma, (3) Mae Ing, and (4) Dien Bien Phu fault zones. (Color online only)

the major-to-great earthquakes $\left(\mathbf{M}_{\mathrm{w}} \geq 7.0\right)$. However, according to the lack of paleoseismological investigations in Laos and the neighborhood areas, this SHA of Laos was focused on the accessible seismicity data.

In order to consider effectively the seismicity affecting to Laos, the earthquake data were collected in a region that extends $300 \mathrm{~km}$ from Laos (Gupta 2002). In the vicinity of Laos (latitude $10.8-25.7^{\circ} \mathrm{N}$ and longitude $96.7-111.0^{\circ} \mathrm{E}$ ), 7540 earthquakes with a magnitude range of $1.0-7.7$ have been reported during 1964 - 2015 by (1) the International Seismological Centre and (2) the US National Earthquake Information Center. For this study, all the earthquakes reported in the $\mathrm{m}_{\mathrm{b}}$ or $\mathrm{M}_{\mathrm{s}}$ scales were converted directly to the $\mathrm{M}_{\mathrm{w}}$ scale using the relationships contributed empirically by the available earthquake data (Figs. 2a and b). Meanwhile, $M_{L}$ scale was converted to $m_{b}$ according to the relationship in Fig. 2c. After that, the obtained $m_{b}$ was re-converted to $\mathrm{M}_{\mathrm{w}}$ scale using the relationship as shown in Fig. 2a. Thereafter, the dependent foreshocks and aftershocks were screened for using the Gardner and Knopoff (1974)'s assumption and deleted. As a result, 1906 main shocks, representing the seismotectonic activities remained. The GENAS algorithm (Habermann 1987) was used to check for man-made artifacts in the earthquake records, as reported previously (Wyss 1991; Zuniga and Wiemer 1999). According to the GENAS algorithm, 1216 events of mainshocks with a $\mathrm{M}_{\mathrm{w}} \geq 3.3$ recorded during 1980 - 2014 conformed to a linear cumulative pattern (Fig. 2d), which implied that these data are complete and meaningful for seismicity investigations, and so were used as the complete dataset in this study.

\section{SEISMMIC ACTIVITIES}

Characterization of the seismic activities at a particular region is commonly expressed in seismic hazard parameters. Based on Kramer (1996), the three parameters that represent the seismic activity and are considered in SHA are the maximum credible earthquake (MCE) and the frequency-magnitude distribution model (FMD) a- and b-coefficient values (Gutenberg and Richter 1944), as expressed in Eq. (1);

$\log (N)=a-b M$

where $N$ is the number of earthquakes with magnitude $\geq M$ generated per year. The a- and b-values are positive constants that vary in both time and space windows.

From Eq. (1) and the plot of the complete earthquake data as the magnitude versus the cumulative number (Fig. 2e), based on the entire-magnitude-range technique (Woessner and Wiemer 2005), the straight line showing the best regression fit indicated FMD a- and b-values of 4.38 and $0.75 \pm 0.03$, respectively. The magnitude of completeness $(\mathrm{Mc})$, which represents the recording capability of the seismic network, was limited at $\mathrm{M}_{\mathrm{w}} \geq 4.2$.

For spatial investigation of the FMD, the study area was divided into $0.25^{\circ} \times 0.25^{\circ}$ cells and earthquakes located within a $200-\mathrm{km}$ radius from each cell were plotted using the 

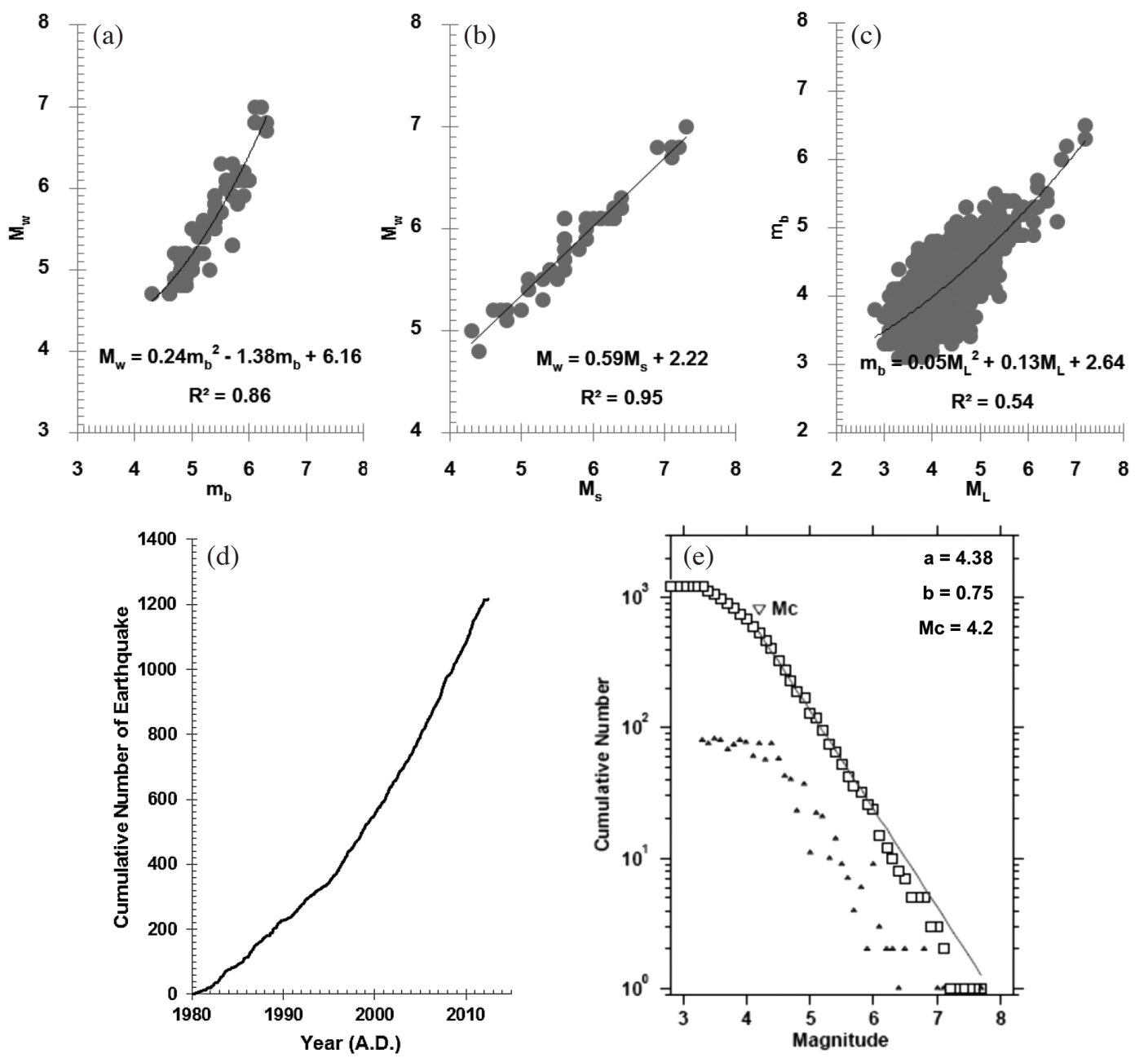

Fig. 2. Relationship of the magnitude scales between (a) $M_{w}-m_{b}$, (b) $M_{w}-M_{S}$, and (c) $m_{b}-M_{L}$ (d) Cumulative number of earthquakes with $M_{w} \geq 3.3$ recorded during 1980 - 2014. (e) The FMD plot of the completeness earthquake data, where the straight line depicts the best fit of the earthquake data.

ZMAP program (Wiemer 2001) as applied successfully by a number of seismicity analysis (i.e., Gambino et al. 2014; Meng and Peng 2014; Özmen et al. 2014). The FMD a- and b-values were then estimated and mapped (Figs. 3a and b). Due to the lack of earthquake data, the FMD plot at Northeastern Thailand, Southern Laos, Vietnam and Cambodia were not available.

Two regions showing prominent high a-values (3.0 5.0), were found at Northern Laos and the Vietnam-Southern China border (Fig. 3a), whereas the areas surrounding Western Thailand and the Thailand-Laos border revealed comparatively low a-values $(0.5-1.0)$. Since the FMD a-value implies seismically the entire rate of seismicity, Northern Laos and the Vietnam-Southern China border area was interpreted as a high seismic activity region (Fig. 3a).

The calculated FMD b-values ranged from $0.4-1.4$ and showed a spatial distribution that was quite similar to that for the FMD a-value (Fig. 3a). In contrast to the FMD a-value, higher FMD b-values imply seismically a lower chance of generating a large earthquake. Thus, the areas conforming to high or low FMD a- and b-values are not congruent and prevent a more exact determination of their seismic hazard status. In order to clarify the earthquake activities, the return period of $\mathrm{M}_{\mathrm{w}}-5.0$ and $\mathrm{M}_{\mathrm{w}}-6.0$ earthquakes were estimated after weighting of both the a- and b-values (Yadav et al. 2011; Figs. 3c and d).

For the return period of a $\mathrm{M}_{\mathrm{w}}-5.0$ earthquake, most of the areas had a short recurrence interval of $0-10 \mathrm{yr}$, although the northeastern part of the study area had a return period of a $\mathrm{M}_{\mathrm{w}}-5.0$ earthquake in the range of $10-25 \mathrm{yr}$ and up to $50 \mathrm{yr}$ in the eastern part of the Southern China (Fig. 3c).

For the return period of a $\mathrm{M}_{\mathrm{w}}-6.0$ earthquake, the different hazardous zones were more clearly illustrated. The first zone, with regionally high seismic activities, was the Myanmar-Southern China border with an estimated return period of $<10 \mathrm{yr}$. The second area is a small stripe of moderate seismic activity that delineates NE-SW along the northern parts of Vietnam, Laos and Thailand and has a return period of around $10-30 \mathrm{yr}$. The third area, with a low seismic activity, was the eastern part of the Vietnam-Southern China 

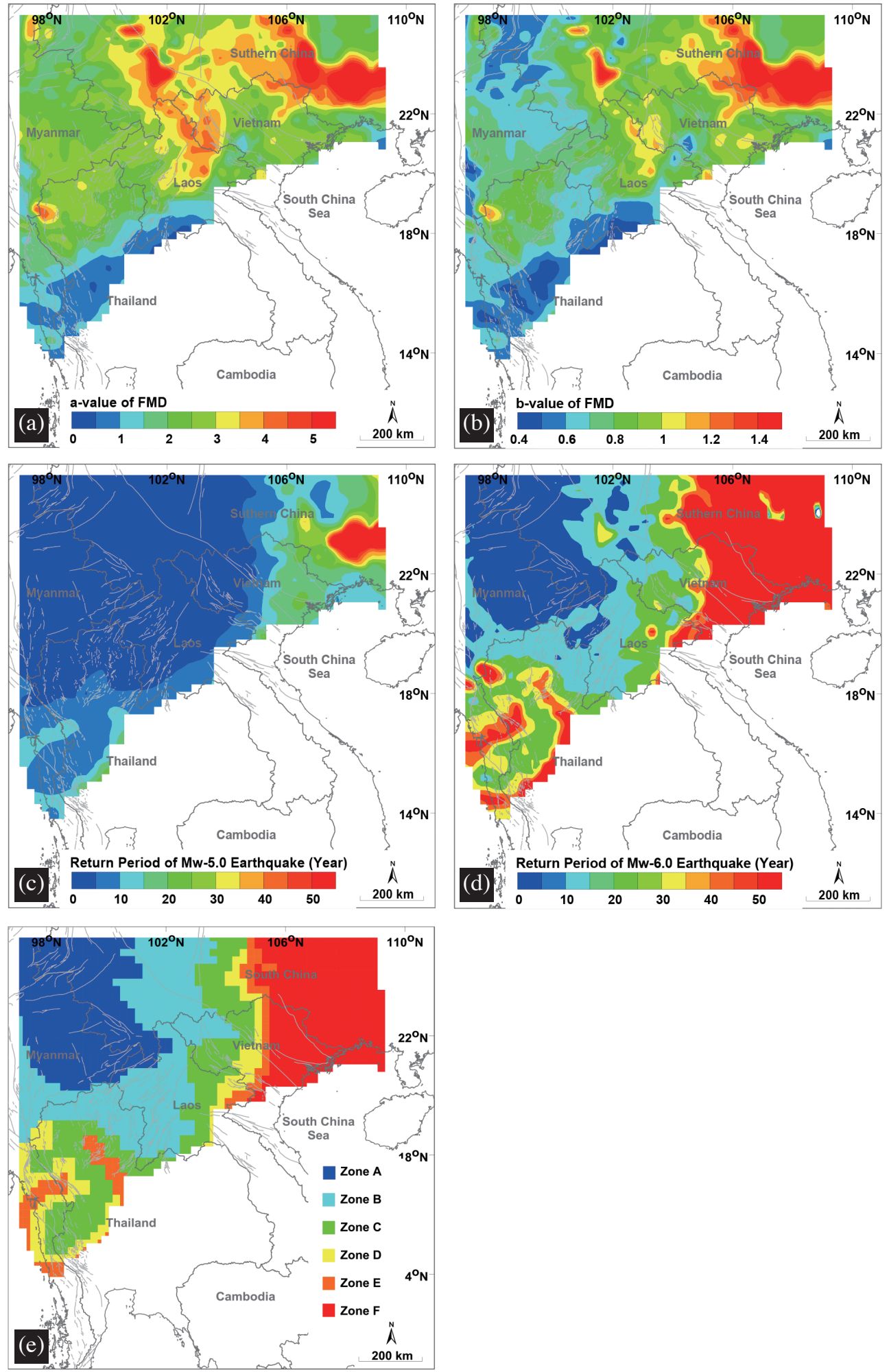

Fig. 3. Maps showing the spatial distributions of the FMD (a) a-value and (b) b-value, and the return periods of earthquak es of (c) $5.0 \mathrm{M}_{\mathrm{w}}$ and (d) $6.0 \mathrm{M}_{\mathrm{w}}$, respectively. (e) six potential seismic source zones (A - F) defined in this study. (Color online only) 
border with a return period of a $\mathrm{M}_{\mathrm{w}}-6.0$ earthquake of up to 40 yr (Fig. 3d).

\section{SEISMIC SOURCE ZONATION AND PARAMETERIZATION}

In SHA, the theoretical identification of seismic source zones needs a complete integration of the geological background, tectonic setting and paleoseismological evidence, including the historical and instrumental earthquake records. However, in practice this data cannot always be perfectly compiled and this is the case here for Laos. Some models of the seismic source zones within the study area have been proposed previously (Nutalaya et al. 1985; Charusiri et al. 2005; Pailoplee and Choowong 2013), but these models suggested that Laos and the adjacent areas were the same seismic source. In order to gain more details in the SHA, in this study the seismic source in Laos and the adjacent areas were newly defined from the return period map of the $\mathrm{M}_{\mathrm{w}}$ 6.0 earthquake (Fig. 3d). As a result, six potential seismic source zones $(\mathrm{A}-\mathrm{F})$ that represent different return periods of $0-10,10-20,20-30,30-40,40-50$, and $>50 \mathrm{yr}$, re- spectively, were proposed (Fig. 3e and Table 1).

In order to provide the earthquake parameters needed for the SHA, the completeness earthquake data located within each defined seismic source zone were collected. The bulk FMD was plotted and the a- and b-values were evaluated for each seismic source (Fig. 4). Due to the lack of paleoseismological data mentioned above, the MCE in each source zone was alternatively estimated based on the maximum earthquake reported in the completeness earthquake

Table 1. Seismic parameters representing the earthquake potential in each of six defined seismic source zones (A - F).

\begin{tabular}{ccccc}
\hline Zone & MCE & FMD a-value & FMD b-value & Mc \\
\hline A & 7.7 & 3.91 & 0.71 & 4.2 \\
B & 7.1 & 3.96 & 0.73 & 4.3 \\
C & 6.5 & 3.58 & 0.75 & 4.0 \\
D & 6.8 & 2.46 & 0.55 & 3.4 \\
E & 6.8 & 2.94 & 0.75 & 3.8 \\
F & 6.8 & 3.34 & 0.74 & 3.8 \\
\hline
\end{tabular}
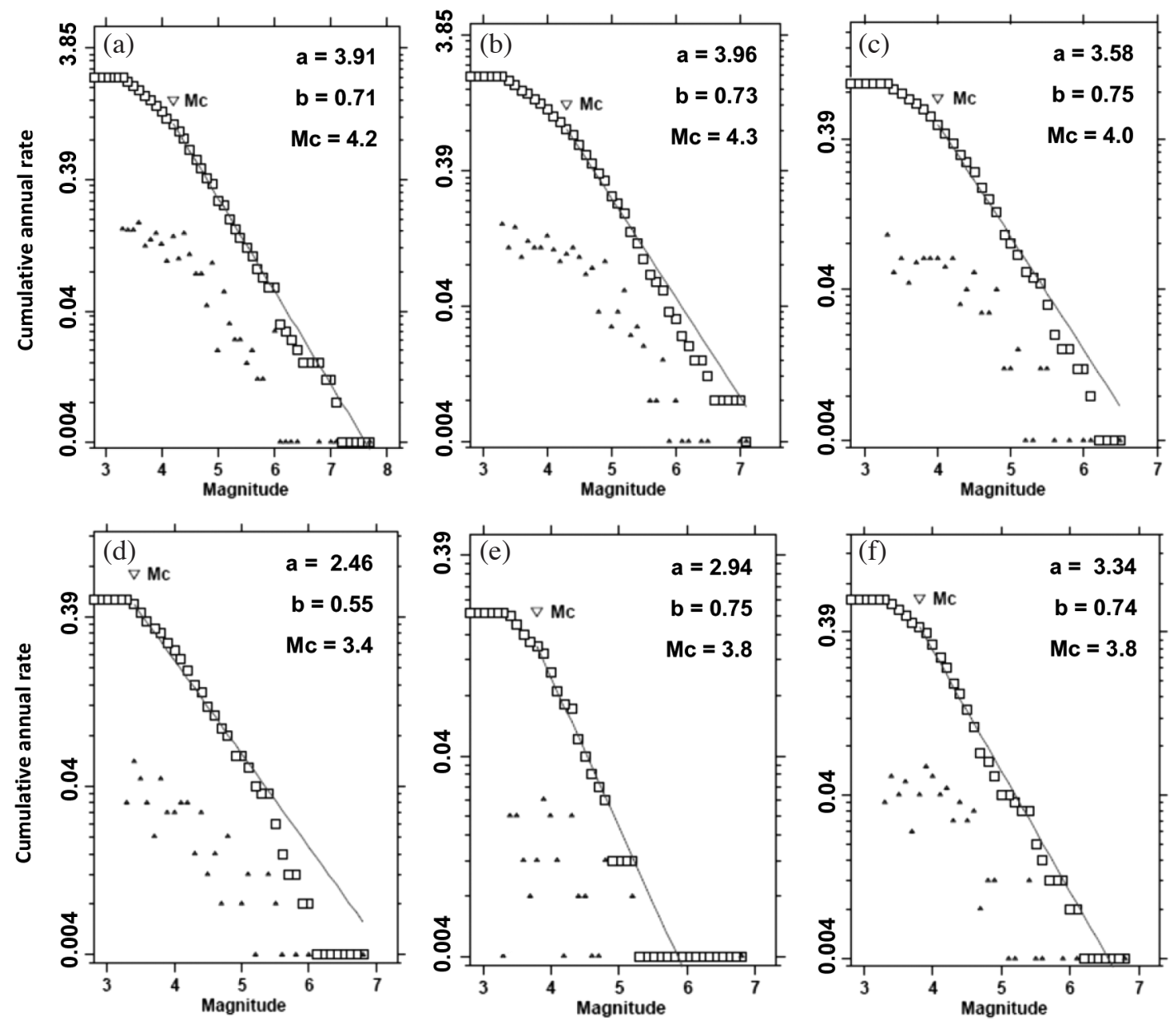

Fig. 4. The FMD plots of the six seismic source zones as illustrated in Fig. 3e. 
catalogue. The details of the seismic parameters evaluated for the six seismic source zones are expressed in Table 1.

\section{SEISMIC HAZARD ANALYSIS}

In the SHA computation, the six areal seismic source zones (section 4) and the territory of Laos were converted equally to $0.25^{\circ} \times 0.25^{\circ}$ grid points. The seismic parameters expressed in Table 1 were then utilized to evaluate the earthquake potential of each seismic source zone. The strong ground-motion attenuation models of Sadigh et al. (1997) [Eq. (2)] were applied as suggested by Chintanapakdee et al. (2008) for Thailand, including the neighborhood areas. Accordingly, the SHA was based on two well-known scenarios of the deterministic and probabilistic seismic hazard analyses, as detailed in sections 5.1 and 5.2, respectively.

$$
\begin{aligned}
\ln (\mathrm{PGA})= & C_{1}+C_{2} M+C_{3}(8.5-M)^{2.5} \\
& +C_{4} \ln \left[R_{r u p}+\exp \left(C_{5}+C_{6} M\right)\right] \\
& +C_{7} \ln \left(R_{r u p}+2\right)
\end{aligned}
$$

According to Eq. (2), the peak horizontal ground acceleration is in $(\mathrm{g})$ for the rock site condition, $M$ means the moment magnitude, $R_{\text {rup }}$ denotes the distance measured from the earthquake source to the site of interest $(\mathrm{km})$, and $C_{1}-C_{7}$ are constants of the relationship (Sadigh et al. 1997). In case of rock site condition, $C_{3}=0, C_{4}=-2.1$, and $C_{7}=0$. For $M \leq$
6.5, $C_{1}=-0.624, C_{2}=1.0, C_{5}=1.297$, and $C_{6}=0.250$ meanwhile for $M>6.5, C_{1}=-1.274, C_{2}=1.1, C_{5}=-0.485$, and $C_{6}$ $=0.524$. The standard deviation $(\sigma)=1.39-0.14 \mathrm{M}$.

\subsection{Deterministic Seismic Hazard Analysis (DSHA)}

Conceptually, the DSHA aims at finding the maximum ground shaking as possible at a given site. This assumption ensures that a structure can withstand the MCE, it will automatically withstand all other (i.e., smaller earthquakes) as well. As a result, according to Krinitzsky (2003), each obtained MCE (Table 1) was assumed to occur within the seismic source zone at the shortest distance from the source to the investigation site. Utilizing the applied attenuation model as expressed in Eq. (2), the seismic hazards were estimated in terms of peak ground acceleration (PGA) without regard to the likelihood of earthquake occurrence.

The obtained DSHA maps of Laos illustrate that the distribution of PGA ranged from $0-0.4 \mathrm{~g}$ (Fig. 5). Usually, the high hazard levels are found in the northern part where a number of seismogenic faults have been defined (Pailoplee et al. 2009). Among the significant provinces of Laos, Louang Namtha province was the most earthquakeprone area with a calculated PGA of up to $0.4 \mathrm{~g}$ from the DSHA. Meanwhile, for Sam Neua, Luang Prabang, Vang Vieng, and Paklay provinces, including the capital city of Laos (Vientiane), the DSHA revealed a PGA in the range of $0.27-0.32 \mathrm{~g}$. In Southern Laos, the seismic hazard was

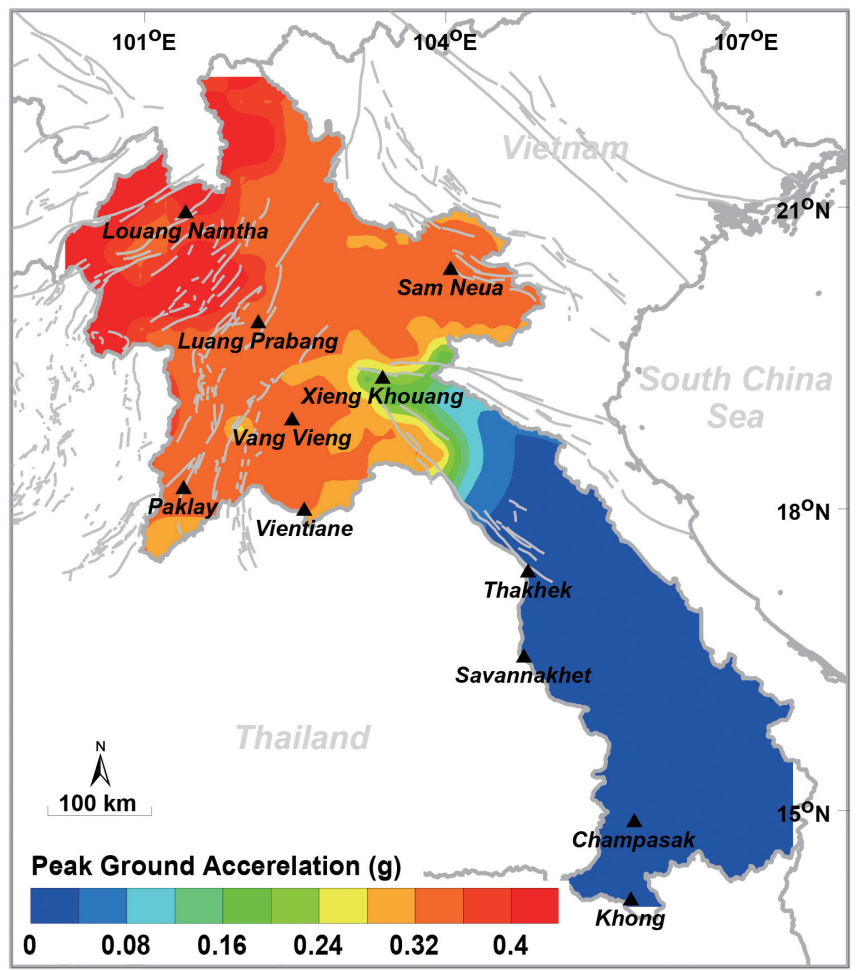

Fig. 5. Possible PGA map of Laos, as evaluated by DSHA. (Color online only) 
quite low and mostly less than $0.04 \mathrm{~g}$. The low-hazard areas were occupied by Thakhek, Savannakhet, Champasak, and Khong provinces (Fig. 5).

\subsection{Probabilistic Seismic Hazard Analysis (PSHA)}

In contrast to the DSHA, PSHA (Cornell 1968) estimates the likelihood $(\lambda)$ that a specific ground-shaking level $(A)$ of interest is equal to or exceeds the ground-shaking level $\left(A_{0}\right)$, as expressed in Eq. (3);

$\lambda\left(A \geq A_{0}\right)=\sum_{i=1}^{N s} v_{i} \iint f_{M i}(m) f_{R i}(r) P\left[A(m, r) \geq A_{0} \mid m, r\right] d m d r$

where $f_{M i}(m)$ is the probability density function of magnitude (Youngs and Coppersmith 1985); $f_{R i}(r)$ is the probability density function for source-to-site distance; $P\left[A(m, r) \geq A_{0} \mid m, r\right]$ is the probability of exceedance (POE) of a threshold value $A_{0}$ depending on $m, r$, and the utilized attenuation model. The term $v_{i}$ is the average rate of earthquake occurrence for an individual seismic source zone $r$ from the total $N s$ recognizing seismic source zones.

Utilizing the CU-PSHA software (Pailoplee and Palasri 2014), the $f_{M i}(m)$ was evaluated for each of the 10 magnitude ranges subdivided between MCE (in $\mathrm{M}_{\mathrm{w}}$ unit)-3.0 $\mathrm{M}_{\mathrm{w}}$. The $f_{R i}(r)$ was estimated in each of the 50 case studies from the longest to shortest distance from the source to site. From each pair of $f_{M i}(m)$ and $f_{R i}(r)$ supplemented by the attenuation model, 200 cases of POE were calculated for a PGA of between 0.005 and 1.995. Then at each investigated site, the hazard curve showing the relationship between the POE and the PGA in the $\mathrm{Y}$ - and $\mathrm{X}$-axis, respectively, was formed.

The hazard curves of some of the major provinces (11 in total) in Laos are shown in Fig. 6, where it is noticeable that Luang Prabang, Louang Namtha, and Paklay provinces are located in a high earthquake hazard region. Meanwhile, Vientiane, and Sam Neua provinces are in a comparatively low seismic hazard area.

With respect to the PSHA map, Kramer (1996) proposed two useful methods for mapping the PSHA based on the hazard curve of the ground shaking map and the probability map, and these are analyzed in turn in sections 5.2.1 and 5.2.2, respectively.

\subsubsection{Ground Shaking Maps}

A ground shaking map illustrates spatially the PGA level (in units of g) that corresponds to a particular POE in the time span of interest (Kramer 1996). In this PSHA, the ground shaking maps for a 2 and $10 \%$ POE in $50 \mathrm{yr}$ were derived (Fig. 7), and were found to be roughly analogous to that obtained from the DSHA (Fig. 5), except that the hazard level was lower in the PSHA than in DSHA. For instance, taking a 2\% POE (Fig. 7a), a high hazard level of $0.24-0.27 \mathrm{~g}$ was found in the northwestern part of Laos, where Louang Namtha, Luang Prabang, Vang Vieng, Paklay, and Sam Neua provinces are located. Meanwhile, the PGA in the northeastern part of Xieng Khouang and Vientiane provinces was around $0.12-0.21 \mathrm{~g}$, which is defined as a comparatively moderate seismic hazard zone in Laos. The lowest seismic hazard in Laos was in the southern part at Thakhek, Savannakhet, Champasak, and Khong provinces, where the calculated PGA was less than $0.04 \mathrm{~g}$ which conforms to the result obtained from the DSHA (Fig. 5).

With regards to the PSHA map of the 10\% POE in the next $50 \mathrm{yr}$ (Fig. 7b), two zones of a different seismic hazard could be classified. The high hazard of PGA $(0.12-0.20 \mathrm{~g})$ dominated the northern part of Laos, whereas the southern part was less than $0.04 \mathrm{~g}$ (Fig. 7b).

\subsubsection{Probability Maps}

Although the ground shaking maps of the PGA levels are more precise, they are not user friendly for informing the public, but rather are typically used more for science and engineering purposes. Therefore, based on Kramer (1996), the probability maps representing simply the POE (\%) of each severity of earthquake hazard were formed. In this study according to the hazard curve of each grid point, the PGA values were converted to the MMI levels based on the empirical PGA-MMI relationship proposed by Pailoplee (2012) for Myanmar and the adjacent areas as shown in Eq. (4);

$\log (\mathrm{PGA})=0.25 \mathrm{MMI}-3.10$

where PGA is in $\left(\mathrm{cm} \mathrm{s}^{-2}\right)$. Thereafter, the POE of MMI levels IV to VII in the next $50 \mathrm{yr}$ were evaluated and mapped (Fig. 8). Two zones could clearly be separated in the probability maps of MMI levels IV and V (Figs. 8a and b), where a high probability was found in the northern part, followed by negligible hazard zones in the southern parts, respectively.

For MMI levels VI (Fig. 8c), the northwestern part still had a POE of more than $70 \%$ in the next $50 \mathrm{yr}$, highlighting the severe seismic hazard in this region. Meanwhile, for the moderate hazard areas of the northeastern part, the POE in the next 50 yr was $40-60 \%$. For the rest of Southern Laos, there was less than a $10 \%$ POE of a MMI level VI in the next $50 \mathrm{yr}$ (Fig. 8c). In addition, for the MMI level VII, the whole country of Laos showed a POE of less than $40 \%$, and in the southern part this was $<10 \%$ (Fig. 8d).

\section{CONCLUSION}

In this study, the seismic activities and hazards were analyzed for Laos. In order to clarify the earthquake sources impacting upon Laos, the available seismicity data were 
analyzed statistically. The earthquake parameters (FMD aand $b$-values and the MCE), including the recurrence intervals of 5.0- $\mathrm{M}_{\mathrm{w}}$ and $6.0-\mathrm{M}_{\mathrm{w}}$ earthquakes were estimated spatially. From this, six seismic source zones were defined for Laos based on the different earthquake recurrence intervals.

Utilizing these seismic source zones and suitable attenuation models, the seismic hazard in this area was analyzed using both deterministic and probabilistic scenarios, and the obtained maps classified Laos into three seismic hazard zones (Table 2).

Although this study is an important step in the earthquake hazard evaluation in Laos, more work is still necessary. In order to constrain both the seismic activities and hazards analyzed here, further studies on the paleoseismology at sites specific to the active faults within and surrounding Laos should be performed.

Acknowledgements This research was supported by the National Research Council of Thailand (NRCT) Fund 2017. Thanks are also extended to T. Pailoplee for the preparation of the draft manuscript. I thank the Publication Counseling Unit (PCU), Faculty of Science, Chulalongkorn University, for a critical review and improved English. I acknowledge thoughtful comments and suggestions by the editors and anonymous reviewers that enhanced the quality of this manuscript significantly.

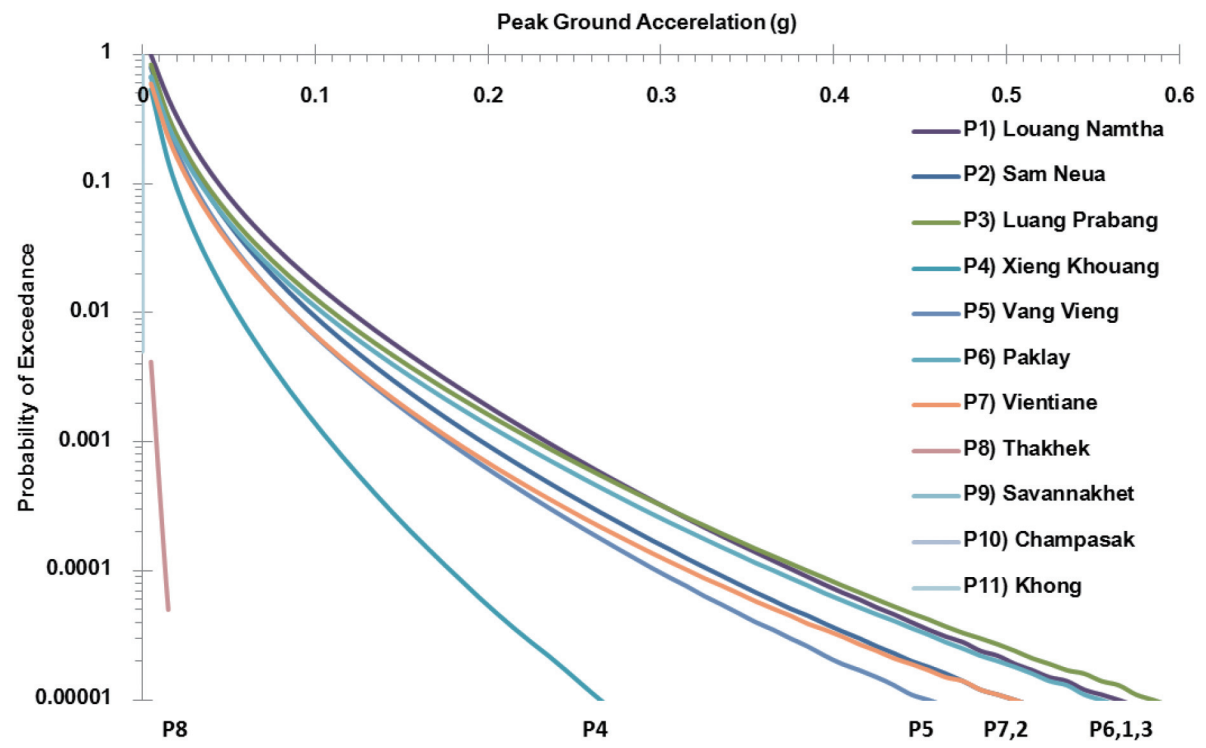

Fig. 6. Hazard curves (PGA vs. POE plots) for the 11 major provinces in Laos, as evaluated by PSHA. (Color online only)
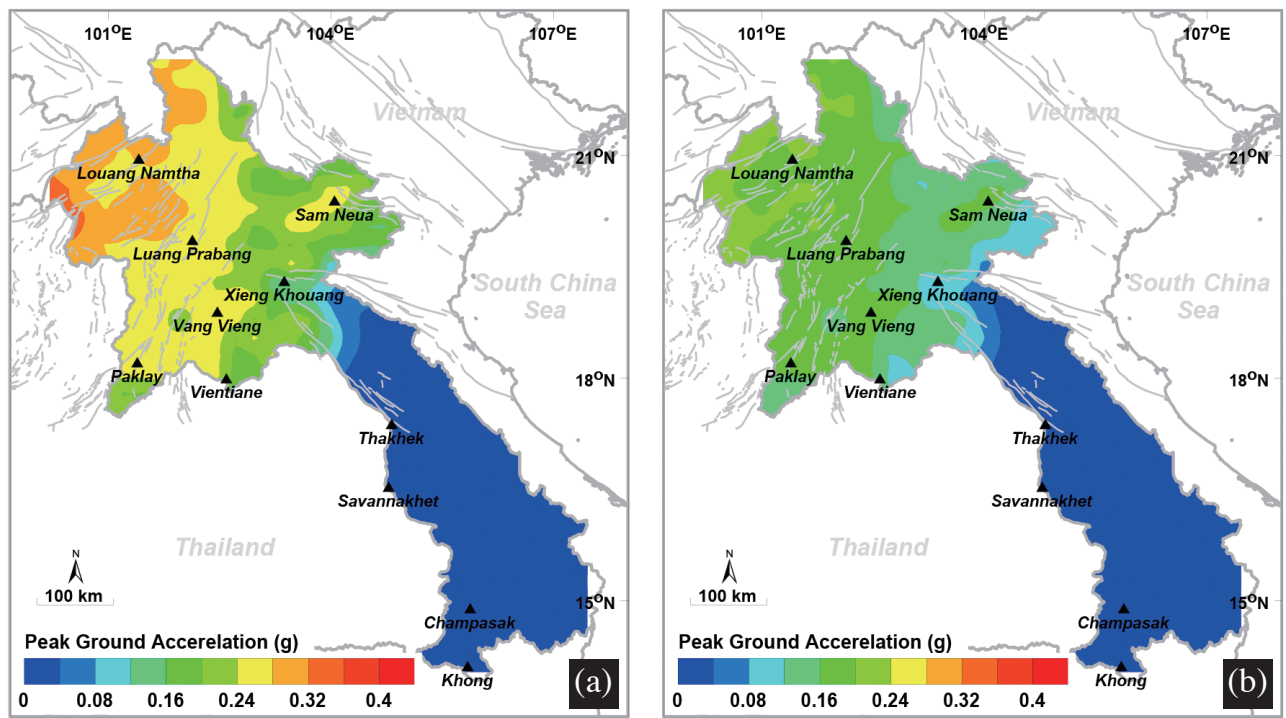

Fig. 7. Probabilistic seismic hazard maps of Laos showing a ground shaking of (a) $2 \%$ and (b) $10 \%$ POE in the next 50 yr. (Color online only) 

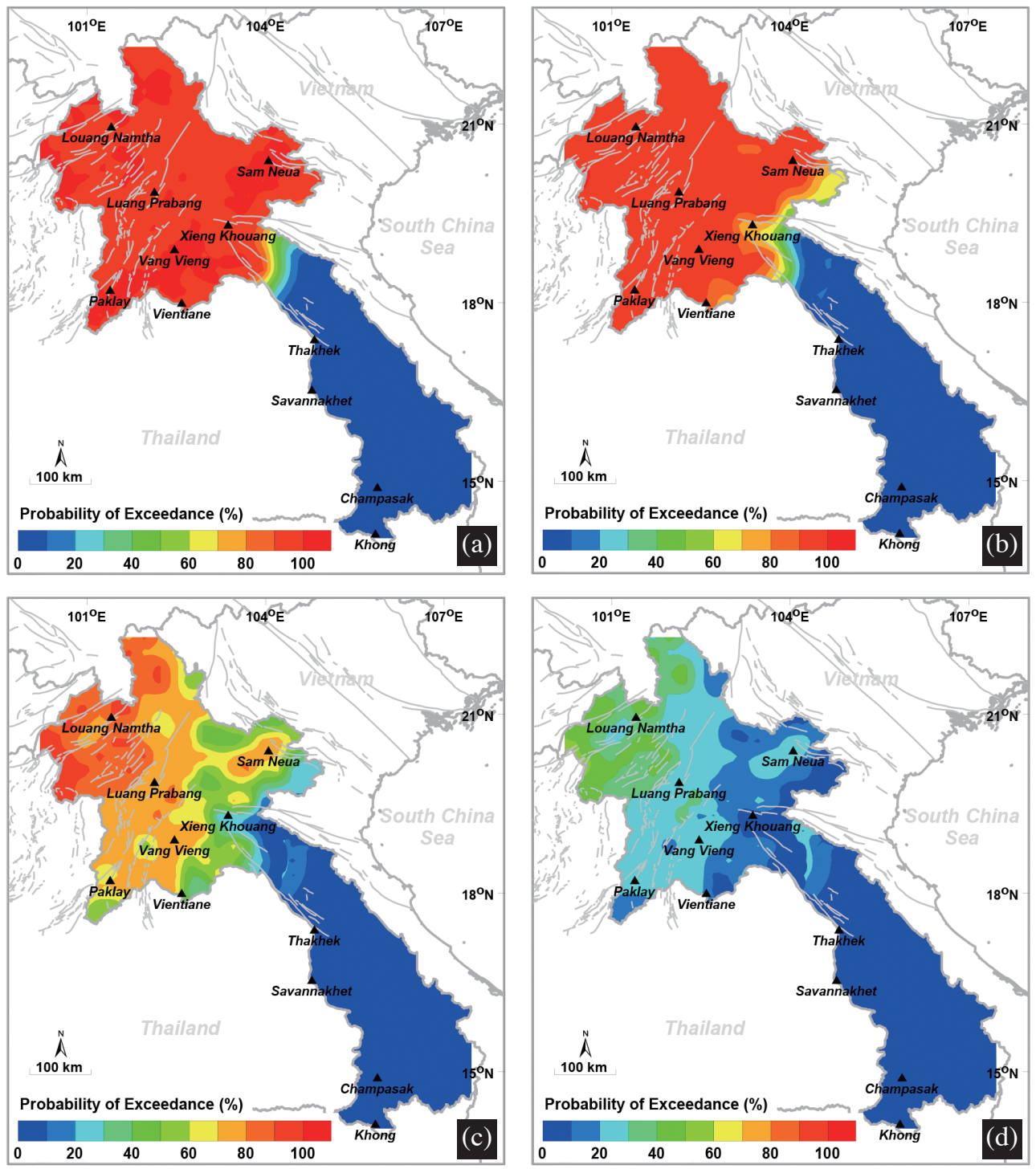

Fig. 8. Probabilistic seismic hazard maps of Laos showing the probabilities (\%) that ground shaking will be equal to or greater than MMI levels of (a) IV, (b) V, (c) VI, and (d) VII in the next 50 yr. (Color online only)

Table 2. Summarized SHA in Laos based on various conditions of interest.

\begin{tabular}{c|ccc}
\hline & Northwestern & Northeastern & Southern \\
\hline Province & $\begin{array}{c}\text { Louang Namtha } \\
\text { Luang Prabang Vang Vieng } \\
\text { Paklay } \\
\text { Sam Neua } \\
\text { DSHA }\end{array}$ & $\begin{array}{c}\text { Xieng Khouang } \\
\text { Vientiane }\end{array}$ & $\begin{array}{c}\text { Thakhek } \\
\text { Savannakhet } \\
\text { Champasak Khong }\end{array}$ \\
\hline PSHA & $0.32-0.4 \mathrm{~g}$ & $0.12-0.32 \mathrm{~g}$ & $<0.12 \mathrm{~g}$ \\
\hline PGA of 2\% POE in 50 yr & $0.24-0.32 \mathrm{~g}$ & $0.12-0.20 \mathrm{~g}$ & $<0.12 \mathrm{~g}$ \\
PGA of 10\% POE in 50 yr & $0.12-0.20 \mathrm{~g}$ & $0.12-0.20 \mathrm{~g}$ & $<0.08 \mathrm{~g}$ \\
POE of MMI IV in 50 yr & $>90 \%$ & $>80 \%$ & $<10 \%$ \\
POE of MMI V in 50 yr & $>90 \%$ & $>80 \%$ & $<10 \%$ \\
POE of MMI VI in 50 yr & $70-90 \%$ & $40-60 \%$ & $<10 \%$ \\
POE of MMI VII in 50 yr & $20-40 \%$ & $10-20 \%$ & $<10 \%$ \\
\hline
\end{tabular}




\section{REFERENCES}

Charusiri, P., M. Choowong, T. Charoentitirat, K. Jankaew, V. Chutakositkanon, and P. Kanjanapayont, 2005: Geological and physical effect evaluation in the tsunami damage area for restoration and warning system. Technical Report, Dept. Geology, Faculty of Science, Chulalongkorn University, 445 pp. (in Thai)

Chintanapakdee, C., M. E. Naguit, and M. Charoenyuth, 2008: Suitable attenuation model for Thailand. The $14^{\text {th }}$ World Conference on Earthquake Engineering, Beijing, China, October 12-17, 8 pp.

Cornell, C. A., 1968: Engineering seismic risk analysis. Bull. Seismol. Soc. Am., 58, 1583-1606.

Duong, C. C. and K. L. Feigl, 1999: Geodetic measurement of horizontal strain across the Red River fault near Thac Ba, Vietnam, 1963-1994. J. Geodesy, 73, 298310, doi: 10.1007/s001900050247. [Link]

Fenton, C. H., P. Charusiri, and S. H. Wood, 2003: Recent paleoseismic investigations in Northern and Western Thailand. Ann. Geophys., 46, 957-981, doi: 10.4401/ ag-3464. [Link]

Gambino, S., A. Laudani, and S. Mangiagli, 2014: Seismicity pattern changes before the $\mathrm{M}=4.8$ aeolian archipelago (Italy) earthquake of august 16, 2010. Sci. World $J .$, 2014, 1-8, doi: 10.1155/2014/531212. [Link]

Gardner, J. K. and L. Knopoff, 1974: Is the sequence of earthquakes in Southern California, with aftershocks removed, Poissonian? Bull. Seismol. Soc. Am., 64, 363-367.

Gupta, I. D., 2002: The state of the art in seismic hazard analysis. ISET J. Earthq. Technol., 39, 311-346.

Gutenberg, B. and C. F. Richter, 1944: Frequency of earthquakes in California. Bull. Seismol. Soc. Am., 34, 185-188.

Habermann, R. E., 1987: Man-made changes of Seismicity rates. Bull. Seismol. Soc. Am., 77, 141-159.

Kramer, S. L., 1996: Geotechnical Earthquake Engineering, Prentice Hall, Inc., Upper Saddle River, New Jersey, 653 pp.

Krinitzsky, E. L., 2003: How to combine deterministic and probabilistic methods for assessing earthquake hazards. Eng. Geol., 70, 157-163, doi: 10.1016/S00137952(02)00269-7. [Link]

Meng, X. and Z. Peng, 2014: Seismicity rate changes in the Salton Sea geothermal field and the San Jacinto Fault Zone after the 2010 MW 7.2 El Mayor-Cucapah earthquake. Geophys. J. Int., 197, 1750-1762, doi: 10.1093/ gji/ggu085. [Link]

Morley, C. K., M. Smith, A. Carter, P. Charusiri, and S. Chantraprasert, 2007: Evolution of deformation styles at a major restraining bend, constraints from cooling histories, Mae Ping fault zone, western Thailand. In: Cunningham, W. D. and P. Mann (Eds.), Tectonics of
Strike-Slip Restraining and Releasing Bends, Geological Society, London, Special Publications, Vol. 290, 325-349, doi: 10.1144/SP290.12. [Link]

Nutalaya, P., S. Sodsri, and E. P. Arnold, 1985: Series on seismology-volume II-Thailand. In: Arnold, E. P. (Ed.), Technical Report, Southeast Asia Association of Seismology and Earthquake Engineering, 402 pp.

Özmen, B., E. Bayrak, and Y. Bayrak, 2014: An investigation of seismicity for the Central Anatolia region, Turkey.J. Seismol., 18, 345-356, doi: 10.1007/s10950013-9411-2. [Link]

Pailoplee, S., 2012: Relationship between modified mercalli intensity and peak ground acceleration in Myanmar. Nat. Sci., 4, 624-630, doi: 10.4236/ns.2012.428082. [Link]

Pailoplee, S. and M. Choowong, 2013: Probabilities of earthquake occurrences in Mainland Southeast Asia. Arab. J. Geosci., 6, 4993-5006, doi: 10.1007/s12517012-0749-5. [Link]

Pailoplee, S. and C. Palasri, 2014: CU-PSHA: A Matlab software for probabilistic seismic hazard analysis. J. Earthq. Tsunami, 8, 1-26, doi: 10.1142/ S1793431114500080. [Link]

Pailoplee, S., Y. Sugiyama, and P. Charusiri, 2009: Deterministic and probabilistic seismic hazard analyses in Thailand and adjacent areas using active fault data. Earth Planets Space, 61, 1313-1325, doi: 10.1186/ BF03352984. [Link]

Sadigh, K., C. Y. Chang, J. A. Egan, F. Makdisi, and R. R. Youngs, 1997: Attenuation relationships for shallow crustal earthquakes based on California strong motion data. Seis. Res. Lett., 68, 180-189, doi: 10.1785/ gssrl.68.1.180. [Link]

Vergnolle, M., E. Calais, and L. Dong, 2007: Dynamics of continental deformation in Asia.J. Geophys. Res., 112, B11403, doi: 10.1029/2006JB004807. [Link]

Wiemer, S., 2001: A software package to analyze seismicity: ZMAP. Seismol. Res., 72, 373-382, doi: 10.1785/ gssrl.72.3.373. [Link]

Woessner, J. and S. Wiemer, 2005: Assessing the quality of earthquake catalogues: Estimating the magnitude of completeness and its uncertainty. Bull. Seismol. Soc. Am., 95, 684-698, doi: 10.1785/0120040007. [Link]

Wyss, M., 1991: Reporting history of the central Aleutians seismograph network and the quiescence preceding the 1986 Andreanof Island earthquake. Bull. Seismol. Soc. Am., 81, 1231-1254.

Yadav, R. B. S., J. N. Tripathi, D. Shanker, B. K. Rastogi, M. C. Das, and V. Kumar, 2011: Probabilities for the occurrences of medium to large earthquakes in northeast India and adjoining region. Nat. Hazards., 56, 145-167, doi: 10.1007/s11069-010-9557-y. [Link]

Youngs, R. R. and K. J. Coppersmith, 1985: Implications of fault slip rates and earthquake recurrence models to probabilistic seismic hazard estimates. Bull. 
Seismol. Soc. Am., 75, 939-964, doi: 10.1016/01489062(86)90651-0. [Link]

Zuchiewicz, W., N. Q. Cuong, A. Bluszcz, and M. Michalik, 2004: Quaternary sediments in the Dien Bien Phu fault zone, NW Vietnam: A record of young tectonic processes in the light of OSL-SAR dating re- sults. Geomorphology, 60, 269-302, doi: 10.1016/j. geomorph.2003.08.004. [Link]

Zuniga, F. R. and S. Wiemer, 1999: Seismicity patterns: Are they always related to natural causes? Pure Appl. Geophys., 155, 713-726, doi: 10.1007/s000240050285. [Link] 